\title{
Attitudes and beliefs of Brazilian physical therapists about chronic low back pain: a cross-sectional study
}

\author{
Atitudes e crenças de fisioterapeutas brasileiros em relação à dor lombar crônica: \\ um estudo transversal
}

Maurício O. Magalhães', Leonardo O. P. Costa ${ }^{1,2}$, Cristina M. N. Cabral', Luciana A. C. Machado 2,3

\begin{abstract}
Objectives: To measure the attitudes and beliefs of Brazilian physical therapists about chronic low back pain and to identify the sociodemographic characteristics that are more likely to influence these attitudes and beliefs. Methods: We conducted a cross-sectional study with 100 Brazilian physical therapists who routinely work with chronic low back pain patients. The attitudes and beliefs were measured by the Pain Attitudes and Beliefs Scale for Physiotherapists (PABS.PT) and the Health Care Providers' Pain and Impairment Relationship Scale (HC-PAIRS). Multivariate linear regression models were built to identify sociodemographic characteristics that could be associated with physical therapists' attitudes and beliefs. Results: Mean scores on the biomedical and biopsychosocial factors of PABS.PT were 27.06 (SD 7.19) and 24.34 (SD 6.31), respectively, and the mean score on HC-PAIRS was 45.45 (SD 10.45). The score on PABS.PT $T_{\text {biomedical }}$ was associated with gender and years of professional experience. No variable was associated with the score on PABS.PT biopsychosocial The score on HC-PAIRS was significantly associated with the number of back pain patients seen by the physical therapist each month. These results indicate that male and less experienced physical therapists tend to follow a biomedical approach to the treatment of chronic low back pain patients, and that the lower the professional experience the stronger the belief in the relationship between pain and disability. Conclusions: Brazilian physical therapists are uncertain of the factors involved in the development and maintenance of chronic low back pain and about the relationship between pain and disability in these patients.
\end{abstract}

Keywords: chronic low back pain; physical therapy; health knowledge; attitudes; practice.

\section{Resumo}

Objetivos: Avaliar as atitudes e crenças de fisioterapeutas brasileiros sobre a dor lombar crônica e identificar características sociodemográficas que as influenciam. Métodos: Este estudo transversal incluiu 100 fisioterapeutas brasileiros que atendem pacientes com dor lombar crônica em sua rotina clínica. As atitudes e crenças foram avaliadas pela Pain Attitudes and Beliefs Scale for Physiotherapists (PABS.PT) e Health Care Providers' Pain and Impairment Relationship Scale (HC-PAIRS). Foram construídos modelos de regressão linear multivariada para verificar as possíveis características sociodemográficas que poderiam estar associadas com as atitudes e crenças dos fisioterapeutas. Resultados: Os escores médios dos fatores biomédico e comportamental da PABS.PT foram 27,06 (DP 7,19) e 24,34 (DP 6,31), respectivamente, e o escore médio da HC-PAIRS foi 45,45 (DP 10,45). O escore do PABS.PT $T_{\text {Fator biomédico }}$ foi associado com gênero e anos de experiência profissional. Já o escore do PABS.PT Fator comportamental $n$ não foi associado com nenhuma variável. O escore do HC-PAIRS foi significativamente associado com o número de pacientes com dor lombar atendido por mês. Esses resultados indicam que fisioterapeutas experientes tendem a seguir uma abordagem biomédica no tratamento de pacientes com dor lombar crônica. Além disso, quanto menor a experiência profissional, mais forte é a crença na relação entre dor e incapacidade. Conclusões: Os fisioterapeutas brasileiros mostram-se incertos acerca dos fatores que envolvem o desenvolvimento e a manutenção da dor lombar crônica e também sobre a relação entre dor e incapacidade nesses pacientes. Isso põe em questão as atitudes e práticas em relação ao manejo dos pacientes com dor lombar crônica no Brasil.

Palavras-chave: dor lombar crônica; fisioterapia; conhecimentos em saúde; atitudes; prática clínica.

Received: 12/12/2011 - Revised: 12/19/2011 - Accepted: 12/22/2011

Master's Program in Physical Therapy, Universidade da Cidade de São Paulo (UNICID), São Paulo, SP, Brazil

${ }^{2}$ Musculoskeletal Division, The George Institute for Global Health, Sydney, NSW, Australia

${ }^{3}$ Faculty of Medicine, Universidade Federal de Minas Gerais (UFMG), Belo Horizonte, MG, Brazil

Correspondence to: Leonardo Oliveira Pena Costa, Rua Cesário Galeno, 448/475, Tatuapé, CEP 03071-000, São Paulo, SP, Brasil, e-mail: Icosta@edu.unicid.br 


\section{Introduction $: \therefore$.}

Low back pain is a significant health problem worldwide and is associated with high levels of disability ${ }^{1-3}$ and elevated societal costs ${ }^{4}$. Chronic low back pain is defined as pain and/or discomfort between the costal margins and the gluteal folds, with or without leg pain, that lasts for more than 12 weeks ${ }^{3}$. Most episodes of low back pain are not related to a specific spinal pathology (e.g., infections, tumors, fractures or nerve root compromise), and the pain is labeled as "non-specific" . A systematic review on the prevalence of non-specific low back pain in 28 countries found that adult lifetime prevalence estimates range between $11 \%$ and $84 \%^{6}$. In Brazil, the 2008 National Household Survey found that chronic low back pain was the second most prevalent chronic condition after systemic arterial hypertension? ${ }^{7}$. The costs associated with chronic low back pain pose a heavy burden on health systems around the world; for example, in the United States, the direct costs for patients with low back pain range between USD12.2 and USD90.6 billion, and these costs represent only $14.5 \%$ of the total expenditure on this condition ${ }^{4}$.

While some patients with chronic low back pain perform their professional and daily life activities normally, others develop significant levels of disability ${ }^{8}$. Some prognostic factors may be able to explain these differences, such as past experiences of pain ${ }^{2}$, lower levels of education ${ }^{2}$, psychological factors ${ }^{9}$, and fear of persistence of pain ${ }^{9}$. Furthermore, preliminary evidence suggests that the attitudes and beliefs of patients about low back pain are associated with therapeutic outcomes ${ }^{10,11}$, levels of disability and quality of life ${ }^{12}$. For example, patients who believe that movement will lead to worsening pain have a higher risk for the persistence of symptoms and higher levels of disability ${ }^{13-15}$. The beliefs of health care professionals who work with patients with chronic low back pain may also interfere with the therapeutic process ${ }^{16}$. For example, health professionals who also associate movement with pain worsening and ask their patients with low back pain to restrict some of their daily life and work activities are more likely to induce significant levels of disability ${ }^{16}$.

There is evidence that educational strategies towards changing patients' and health professionals' beliefs about low back pain can reduce pain and disability ${ }^{17,18}$. A study conducted in Australia ${ }^{18}$ investigated the effect of a media campaign on the attitudes and beliefs of approximately 6,000 patients with low back pain over a three-year period. The impact of the media campaign on patients' fear of movement and back pain beliefs was measured through the Fear Avoidance Beliefs Questionnaire $^{19}$ (FABQ) and the Back Beliefs Questionnaire (BBQ) ${ }^{20}$, respectively. The study found clinically significant improvement for both outcomes, suggesting that primary prevention strategies that focus on a population's beliefs can be an effective form of preventing high levels of disability in patients with low back pain ${ }^{18}$.

In general, physical therapists can have two distinct attitudes towards treatment and advice for patients with chronic low back pain ${ }^{21}$. The first follows a biomedical model based on the theory that pain and disability derive exclusively from a structural and/or functional alteration to the spine and/or adjacent areas. In this model, pain is considered to be indicative of tissue damage and physical therapy treatment essentially targets the impaired anatomical structures ${ }^{21}$. The second attitude is one that follows a biopsychosocial model in which pain is explained not only by tissue damage but also by social and psychological factors ${ }^{21}$. In this case, physical therapy treatment is based on principles of cognitive behavioral therapy that address these factors. This approach has been shown to be cost-effective ${ }^{22}$, and it is the treatment of choice currently recommended by the available clinical practice guidelines, including the guidelines from the American College of Physicians and the American Pain Society for the treatment of patients with non-specific chronic low back pain ${ }^{23}$.

Studies on research priorities in low back pain considered "attitudes and beliefs" as one of the five main priorities for future research in this area ${ }^{24-26}$. Only one study ${ }^{27}$ evaluating attitudes and beliefs towards low back pain has been conducted in Brazil. The study by Ferreira et al. ${ }^{27}$ measured the attitudes and beliefs of 153 Brazilian physical therapy students, who had not yet taken the subject on low back pain and compared the results to those of 618 Australian physical therapy students. Students' beliefs and attitudes were measured by the Health Care Providers' Pain and Impairment Relationship Scale (HC-PAIRS) ${ }^{8}$. Brazilian physical therapy students showed a stronger belief that low back pain is associated with levels of disability and limitations in daily life and work activities, when compared to Australian students ${ }^{27}$. The attitudes and beliefs of physical therapy graduates who routinely work with patients with low back pain have not been previously investigated in Brazil. Therefore, the primary aim of this study was to measure the attitudes and beliefs of Brazilian physical therapists towards the development and maintenance of chronic low back pain. A secondary aim of this study was to determine which sociodemographic characteristics would be associated with their attitudes and beliefs.

\section{Methods: :}

\section{Sample and procedures}

This is a secondary analysis of data from a study that translated and cross-culturally adapted the PABS-PT into 
Brazilian Portuguese and tested the measurement properties of the Brazilian Portuguese versions of the PABS-PT and HC-PAIRS in Brazilian physical therapists ${ }^{28}$. One hundred physical therapists from four Brazilian capital cities (São Paulo, Belo Horizonte, Maceió and Belém) were recruited by convenience. Registered physical therapists reporting previous experience in treating patients with low back pain (i.e. by treating at least one patient per week on average) were eligible for inclusion in the study. After the invitation to participate in the study, physical therapists were asked to sign a consent form and then to complete two self-report scales for the assessment of their attitudes and beliefs about chronic low back pain: the HC-PAIRS ${ }^{8,28}$ and the Pain Attitudes and Beliefs Scale for Physiotherapists (PABS.PT) ${ }^{28,29}$.

\section{Instruments}

\section{Health Care Providers' Pain and Impairment Relationship Scale (HC-PAIRS)}

The HC-PAIRS was developed from the Pain and Impairment Relationship Scale (PAIRS), which was originally developed to evaluate the attitudes and beliefs of patients with chronic low back pain ${ }^{30}$. Fifteen items that suggest a direct relationship between pain and disability are scored according to a seven-point Likert scale (ranging from $0=$ "totally disagree" to $6=$ "totally agree"). The total score for the HC-PAIRS ranges from 0 to 90 points, with higher scores representing stronger beliefs in the relationship between chronic pain and disability. The clinimetric properties of the HC-PAIRS are acceptable, including adequate internal consistency and discriminating validity $^{8}$. In this study we used the Brazilian-Portuguese version of the HC-PAIRS, which has been previously translated and cross-culturally adapted, and presents acceptable clinimetric properties $^{27,28}$.

\section{Pain Attitudes and Beliefs Scale for Physiotherapists (PABS.PT)}

The PABS.PT was developed to evaluate the role of physical therapists' attitudes and beliefs on the development and maintenance of chronic low back pain ${ }^{21}$. A previous factor analysis of the scale indicated two discrete factors: biomedical (items 1 to 10) and biopsychosocial (items 11 to 19) ${ }^{31}$. The items for both factors are scored on a 6-point Likert scale ( $0=$ "totally disagree" to $5=$ "totally agree"). The score for the

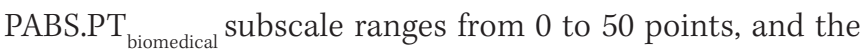
score for the PABS.PT biopsychosocial $_{\text {subscale ranges from } 0 \text { to } 45}$ points. A high score on the PABS.PT biomedical $_{\text {subscale repre- }}$ sents a belief in the relationship between low back pain and tissue damage, while a high score on the PABS.PT $\mathrm{b}_{\text {biopsychosocial }}$ subscale indicates a belief in the influence of psychological and social as well as biological factors ${ }^{21}$. In this study we used the Brazilian-Portuguese version of the PABS.PT, which has also been previously translated and cross-culturally adapted, and presents acceptable clinimetric properties ${ }^{28}$.

This study was approved by the Ethics Committee of Pontifícia Universidade Católica de Minas Gerais (PUCMG), Belo Horizonte, MG, Brazil (number FR-146074).

\section{Statistical analysis}

Descriptive statistics was used to summarize participants' sociodemographic data and scores on the HC-PAIRS and PABS. PT. Data normality was verified through the visual inspection of histograms, with all variables being normally distributed.

Univariate and multivariate linear regression analyses were used to investigate sociodemographic characteristics that could be associated with the beliefs and attitudes measured by the two scales. The scores on the HC-PAIRS and PABS.PT subscales were used as dependent variables. The following independent variables were selected $a$ priori: age; gender (coded as $0=$ male and $1=$ female); years of professional experience; use of a specific treatment approach (coded as $0=$ no and $1=y e s$, if the participants stated that they use any specific approach); number of patients with low back pain seen by the physical therapist each month. Although we considered the variables "main work location" and "highest academic degree" for possible inclusion in the regression models, these variables do not satisfy the assumption of linearity with the dependent variables.

Independent variables showing an association of $p \leq 0.20^{32}$ with the dependent variable in the univariate model were selected for inclusion in the multivariate model. The multivariate model was built using the backward elimination technique ${ }^{32}$ until all independent variables were associated with the dependent variable at the $\mathrm{p}<0.05$ level. We used the SPSS 18.0 for Windows for all analyses.

\section{Results : : :}

A total of 123 physical therapists were invited to participate in the study and $100(81.3 \%)$ agreed to participate. All participants were young adults with an average of six years of professional experience. Table 1 lists the main characteristics of the participants. Table 2 shows the results of the evaluation of participants' beliefs and attitudes about chronic low back pain.

Of the five sociodemographic variables entered into the regression models, only gender (beta coefficient $=3.34 ; 95 \% \mathrm{CI}$ 0.61 to $6.06 ; \mathrm{p}=0.02$ ) and years of professional experience (beta coefficient $=-0.29$; $95 \% \mathrm{CI}-0.53$ to $-0.06 ; \mathrm{p}=0.02$ ) were significantly associated with the score on PABS.PT biomedical This result indicates that male and less experienced physical therapists 
(with regards to years of professional experience) were more likely to follow a biomedical approach to the treatment of patients with chronic low back pain. No variable was associated with the score on PABS.PT ${ }_{\text {biopsychosociall }}$ The only variable that was significantly associated with the HC-PAIRS score was the number of patients with low back pain seen by the physical therapist each month (beta coefficient $=-0.20$; 95\%CI -0.39 to $-0.01 ; p=0.04)$, indicating that the lower the number of patients

Table 1. Characteristics of the participants.

\begin{tabular}{|c|c|}
\hline \multicolumn{2}{|l|}{ Variable } \\
\hline \multicolumn{2}{|l|}{ Gender } \\
\hline Male & $51 \%$ \\
\hline Female & $49 \%$ \\
\hline Age (years) & $27.44(5.72)$ \\
\hline Number of patients with low back pain seen per month* & $8(7)$ \\
\hline Years of professional experience & $5.60(5.73)$ \\
\hline \multicolumn{2}{|l|}{ University training } \\
\hline Public & $23 \%$ \\
\hline Private & $77 \%$ \\
\hline \multicolumn{2}{|l|}{ Highest academic degree } \\
\hline Bachelor & $20 \%$ \\
\hline Master's by coursework & $63 \%$ \\
\hline Master's by research & $12 \%$ \\
\hline Doctorate & $3 \%$ \\
\hline Not reported & $2 \%$ \\
\hline \multicolumn{2}{|l|}{ Use of specific treatment approach } \\
\hline Yes & $44 \%$ \\
\hline McKenzie Method & $4 \%$ \\
\hline Motor Control (Specific Stabilization Exercises) & $6 \%$ \\
\hline Global Postural Re-education & $14 \%$ \\
\hline Pilates & $1 \%$ \\
\hline Osteopathy & $10 \%$ \\
\hline Other & $9 \%$ \\
\hline No & $56 \%$ \\
\hline \multicolumn{2}{|l|}{ Main work location } \\
\hline Private office & $21 \%$ \\
\hline Public hospital & $21 \%$ \\
\hline Private physical therapy clinic & $20 \%$ \\
\hline Private multidisciplinary clinic & $10 \%$ \\
\hline Public physical therapy clinic & $11 \%$ \\
\hline Home care & $9 \%$ \\
\hline Fitness center & $4 \%$ \\
\hline Private hospital & $2 \%$ \\
\hline Not reported & $2 \%$ \\
\hline
\end{tabular}

seen per month by the physical therapist the stronger the belief in the relationship between pain and disability.

\section{Discussion $: \because$.}

The scores on the two scales used in the present study were very close to their midpoint values. This result may indicate an uncertainty among physical therapists regarding their treatment orientation (i.e., biomedical or biopsychosocial). Three previous studies reported similar scores for $\mathrm{PABS}_{\mathrm{PT}} \mathrm{T}_{\text {biomedical }}$ but higher scores for PABS.PT biopsychosocial $^{16,21,33}$. Houben et al. ${ }^{21}$ recruited 297 Dutch healthcare providers (physical therapists, chiropractors, manual therapists, and osteopaths) and found

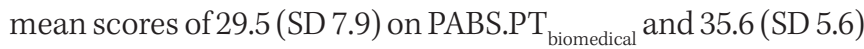
on PABS.PT biopsychosocial Bishop et al. ${ }^{16}$ assessed 580 physical therapists in the United Kingdom, and the mean scores on PABS. $\mathrm{PT}_{\text {biomedical }}$ and PABS.PT biopsychosocial $_{\text {were }} 31.1$ (SD 7.2) and 32.5 (SD 4.8), respectively. Finally, the study by Fullen et al. ${ }^{33}$ was conducted in 423 general practitioners in Ireland and found mean scores on PABS.PT biomedical and PABS.PT biopsychosocial of 38.8 (SD 7.7) and 16.3 (SD 3.1), respectively.

The difference between the scores on PABS.PT $\mathrm{biopsychosocial}_{\text {of }}$ these previous studies and the present study may be explained by a combination of sampling differences, including cultural aspects, type of academic training and professional experience, or by differences in the curricular structure of university programs in different countries. Another possible explanation is that these previous studies were conducted in European countries, where most biopsychosocial theories/treatments have been developed and where the incorporation of the biopsychosocial model is stronger among healthcare providers ${ }^{34}$ (e.g., cognitivebehavioral principles are fully integrated into physical therapy management of patients with low back pain ${ }^{34-37}$ ).

The attitudes and beliefs of healthcare providers are intimately associated with their clinical decision-making. For example, healthcare professionals with a stronger biomedical profile tend to prescribe more imaging exams to search for specific causes of chronic low back pain and to encourage patients to rest and take time away from work in an attempt to reduce tissue damage ${ }^{38}$. However, clinical practice guidelines for the management of chronic low back pain do not recommend such prescriptions because there is sufficient evidence

Table 2. Scores for the evaluation of participants' beliefs and attitudes.

\begin{tabular}{lcccc}
\hline Scale & Mean (SD) & Median & $2^{\text {th }}$ Percentile & $75^{\text {th }}$ Percentile \\
\hline PABS.PT $_{\text {biomedical (0-50) }}$ & $27.06(7.19)$ & 27.00 & 23.00 & 31.75 \\
\hline PABS.PT $_{\text {biopsychosocial (0-45) }}$ & $24.34(6.31)$ & 24.00 & 20.00 & 29.00 \\
\hline HC-PAIRS $_{(0-90)}$ & $45.45(10.45)$ & 45.00 & 39.00 & 51.75 \\
\hline
\end{tabular}


showing that these actions do not help patients with this condition ${ }^{3}$. Conversely, active exercise and the avoidance of bed rest/work absence are recommended by the guidelines ${ }^{3}$, reflecting the relevance of the biopsychosocial approach for this condition.

One previous study ${ }^{29}$ reported strong beliefs in the relationship between chronic pain and disability among 156 Dutch healthcare providers. In that study, the majority of the sample were physical therapists, manual therapists, chiropractors and few (5.4\%) therapists who used the McKenzie method of treatment ${ }^{39}$, and the mean score on the HC-PAIRS was 48.1 (SD 9.4) ${ }^{29}$. One can assume that this particular sample included a large group of professionals who had a strong biomedical profile, given that their main treatment approach is one that relies upon the presence of tissue damage or structural abnormality and uses objective strategies to heal the damage/abnormality (i.e., a chiropractor would manipulate the vertebrae to reduce a subluxation). In contrast, the majority of physical therapists included in our sample did not use a specific treatment approach for the management of their patients, which probably explains why we were unable to indicate a direction for the beliefs of physical therapists about the relationship between chronic pain and disability.

Differences in the beliefs of healthcare providers with diverse educational training were also evident in another study ${ }^{8}$ comparing 150 health professionals (authors did not specify their professional background) with 66 "functional restoration therapists". The average scores on the HC-PAIRS were 52.00 (SD 10.00) for the former and 38.00 (SD 7.00) for the later. ${ }^{8}$. It is worth noting that this study used a Likert scale ranging from 1-7 while our study used a 0-6 scale, therefore we can conclude that the Brazilian estimates of HC-PAIRS scores were higher than American health care professionals.

Among the variables entered into the regression analyses, male gender and years of professional experience were significantly associated with the score on PABS.PT biomedical The number of patients with low back pain who were seen by the physical therapist per month was the only variable associated with the HC-PAIRS score. Similar analyses were performed in two previous studies. Fullen et al. ${ }^{33}$ found a significant association between female gender and the PABS.PT score. In the study conducted by Houben et $1 .{ }^{29}$, the vasschosocia that were significantly associated with the HC-PAIRS score were the severity of symptoms and the years of experience in treating patients with low back pain. A common aspect between these studies and the present study is a greater biopsychosocial focus among female and more experienced healthcare providers (considered either as the time in the profession or the number of patients with low back pain seen in a particular period of time).

The present study is the first to evaluate the attitudes and beliefs of Brazilian physical therapists about patients with chronic low back pain. One of the strengths of our study was the inclusion of physical therapists from various cities and with different levels of academic training. Although we think that our sample might be representative, there is no available demographic data (from registration boards, for example) to determine if our sample is truly representative of all Brazilian physical therapists. Nonetheless, the sample size in this study was smaller than those of earlier studies ${ }^{16,33}$, which makes our study less representative when compared to European studies.

It is critical that future studies evaluate ideal cut-off points for the PABS.PT in order to assist interpretation about the orientation (biomedical or biopsychosocial) of healthcare professionals towards the treatment of patients with chronic low back pain. Additionally, it would be interesting to compare the attitudes and beliefs of Brazilian physical therapists to those of other healthcare professionals involved in the treatment of these patients. Finally, further investigations should focus on changing the attitudes and beliefs of healthcare professionals and patients and on their impact on patient recovery.

\section{References $\because:$.}

1. Henschke N, Ostelo RW, van Tulder MW, Vlaeyen JW, Morley S, Assendelft WJ, et al. Behavioural treatment for chronic low-back pain. Cochrane Database Syst Rev. 2010(7):CD002014.

2. Costa Lda C, Maher CG, McAuley JH, Hancock MJ, Herbert RD, Refshauge KM, et al. Prognosis for patients with chronic low back pain: inception cohort study. BMJ. 2009;339:b3829.

3. Airaksinen O, Brox JI, Cedraschi C, Hildebrandt J, Klaber-Moffett J, Kovacs F, et al. Chapter 4. European guidelines for the management of chronic nonspecific low back pain. Eur Spine J. 2006;15 Suppl 2:\$192-300.

4. Dagenais S, Caro J, Haldeman S. A systematic review of low back pain cost of illness studies in the United States and internationally. Spine J. 2008;8(1):8-20.

5. Burton AK, Balague F, Cardon G, Eriksen HR, Henrotin Y, Lahad A, et al. Chapter 2 European guidelines for prevention in low back pain: November 2004. Eur Spine J. 2006;15 Suppl 2:S136-68.

6. Walker BF. The prevalence of low back pain: a systematic review of the literature from 1966 to 1998. J Spinal Disord. 2000;13(3):205-17.

7. Brazilian Institute of Geography and Statistics (IBGE). Brazilian Institute of Geography and Statistics (IBGE): National Sampling Study of Households. A Panorama of Health in Brazil: access 
to and utilization of services, health conditions and risk factors and protection of health. 2008 [04/07/2011]; Available from: http://bvsms.saude.gov.br/bvs/publicacoes/pnad_panorama_ saude_brasil.pdf.

8. Rainville J, Bagnall D, Phalen L. Health care providers' attitudes and beliefs about functional impairments and chronic back pain. Clin J Pain. 1995;11(4):287-95.

9. Pincus T, Vogel S, Burton AK, Santos R, Field AP. Fear avoidance and prognosis in low back pain: a systematic review and synthesis of current evidence. Arthritis Rheum. 2006;54(12):3999-4010.

10. Truchon M. Determinants of chronic disability related to low back pain: towards an integrative biopsychosocial model. Disabil Rehabil. 2001;23(17):758-67.

11. Turner JA, Clancy S. Strategies for coping with chronic low back pain: relationship to pain and disability. Pain. 1986;24(3):355-64.

12. Thomas EN, Pers YM, Mercier G, Cambiere JP, Frasson N, Ster F, et al. The importance of fear, beliefs, catastrophizing and kinesiophobia in chronic low back pain rehabilitation. Ann Phys Rehabil Med. 2010;53(1):3-14

13. Coudeyre E, Tubach F, Rannou F, Baron G, Coriat F, Brin S, et al. Fear-avoidance beliefs about back pain in patients with acute LBP. Clin J Pain. 2007;23(8):720-5.

14. Kovacs FM, Seco J, Royuela A, Peña A, Muriel A; Spanish National Health Service. The correlation between pain, catastrophizing, and disability in subacute and chronic low back pain: a study in the routine clinical practice of the Spanish National Health Service. Spine (Phila Pa 1976). 2011;36(4):339-45.

15. Urquhart DM, Bell RJ, Cicuttini FM, Cui J, Forbes A, Davis SR. Negative beliefs about low back pain are associated with high pain intensity and high level disability in community-based women. BMC Musculoskelet Disord. 2008;9:148.

16. Bishop A, Foster NE, Thomas E, Hay EM. How does the self-reported clinical management of patients with low back pain relate to the attitudes and beliefs of health care practitioners? A survey of UK general practitioners and physiotherapists. Pain. 2008;135(1-2):187-95

17. Coudeyre E, Tubach F, Rannou F, Baron G, Coriat F, Brin S, et al. Effect of a simple information booklet on pain persistence after an acute episode of low back pain: a non-randomized trial in a primary care setting. PLoS One. 2007;2(8):e706.

18. Buchbinder R, Jolley D. Effects of a media campaign on back beliefs is sustained 3 years after its cessation. Spine (Phila Pa 1976). 2005;30(11):1323-30.

19. Waddell G, Newton M, Henderson I, Somerville D, Main CJ. A Fear-Avoidance Beliefs Questionnaire (FABQ) and the role of fear-avoidance beliefs in chronic low back pain and disability. Pain. 1993;52(2):157-68.

20. Symonds TL, Burton AK, Tillotson KM, Main CJ. Do attitudes and beliefs influence work loss due to low back trouble? Occup Med (Lond). 1996;46(1):25-32.

21. Houben RM, Ostelo RW, Vlaeyen JW, Wolters PM, Peters M, Stomp-van den Berg SG. Health care providers' orientations towards common low back pain predict perceived harmfulness of physical activities and recommendations regarding return to normal activity. Eur J Pain. 2005:9(2):173-83.

22. Lin CW, Haas M, Maher CG, Machado LA, van Tulder MW. Cost-effectiveness of guidelineendorsed treatments for low back pain: a systematic review. Eur Spine J. 2011;20(7):1024-38.

23. Chou R, Qaseem A, Snow V, Casey D, Cross JT Jr, Shekelle P, et al. Diagnosis and treatment of
Iow back pain: a joint clinical practice guideline from the American College of Physicians and the American Pain Society. Ann Intern Med. 2007;147(7):478-91.

24. Borkan JM, Cherkin DC. An agenda for primary care research on low back pain. Spine (Phila Pa 1976). 1996;21(24):2880-4.

25. Borkan JM, Koes B, Reis S, Cherkin DC. A report from the Second International Forum for Primary Care Research on Low Back Pain. Reexamining priorities. Spine (Phila Pa 1976). 1998;23(18):1992-6.

26. Costa Lda C, Pransky G, Koes B, Maher C, Smeets R, Borkan JM, editors. The new agenda for primary care research on low back pain. Primary Care Research On Low Back Pain. 2011; 164: Melbourne.

27. Ferreira PH, Ferreira ML, Latimer J, Maher CG, Refshauge K, Sakamoto A, et al. Attitudes and beliefs of Brazilian and Australian physiotherapy students towards chronic back pain: a crosscultural comparison. Physiother Res Int. 2004;9(1):13-23.

28. Magalhães MO, Costa LO, Ferreira ML, Machado LA. Clinimetric testing of two instruments tha measure attitudes and beliefs of health care providers about chronic low back pain. Rev Bras Fisioter. 2011;15(3):249-56.

29. Houben RM, Vlaeyen JW, Peters M, Ostelo RW, Wolters PM, Stomp-van den Berg SG. Health care providers' attitudes and beliefs towards common low back pain: factor structure and psychometric properties of the HC-PAIRS. Clin J Pain. 2004;20(1):37-44.

30. Riley JF, Ahern DK, Follick MJ. Chronic pain and functional impairment: assessing beliefs about their relationship. Arch Phys Med Rehabil. 1988;69(8):579-82.

31. Ostelo RW, Stomp-van den Berg SG, Vlaeyen JW, Wolters PM, de Vet HC. Health care provider's attitudes and beliefs towards chronic low back pain: the development of a questionnaire. Man Ther. 2003;8(4):214-22

32. Altman DG. Practical statistics for medical researched. London: Chapman and Hall; 1991.

33. Fullen BM, Baxter GD, Doody C, Daly LE, Hurley DA. General Practitioners' attitudes and beliefs regarding the management of chronic low back pain in Ireland: a cross-sectional national survey. Clin J Pain. 2011;27(6):542-9.

34. Sullivan MJL, Adams H. Psychosocial treatment techniques to augment the impact of physiotherapy interventions for low back pain. Physiother Can. 2010;62(3):180-9.

35. Hansen Z, Daykin A, Lamb SE. A cognitive-behavioural programme for the management of low back pain in primary care: a description and justification of the intervention used in the Back Skills Training Trial (BeST; ISRCTN 54717854). Physiotherapy. 2010;96(2):87-94.

36. Hay EM, Mullis R, Lewis M, Vohora K, Main CJ, Watson P, et al. Comparison of physica treatments versus a brief pain-management programme for back pain in primary care: a randomised clinical trial in physiotherapy practice. Lancet. 2005;365(9476):2024-30.

37. van der Windt D, Hay E, Jellema P, Main C. Psychosocial interventions for low back pain in primary care: lessons learned from recent trials. Spine (Phila Pa 1976). 2008;33(1):81-9.

38. Darlow B, Fullen BM, Dean S, Hurley DA, David Baxter G, Dowell A. The association between health care professional attitudes and beliefs and the attitudes and beliefs, clinical management, and outcomes of patients with low back pain: A systematic review. Eur J Pain. 2011(Epub Ahead of print).

39. McKenzie R, May S. The lumbar spine: Mechanical Diagnosis \& Therapy. Vol 1. New Zealand: Spinal Publications; 2003 